\title{
Quality of Life among Patients with Hepatorenal Syndrome
}

\author{
ENTESAR S.M. AHMAD, M.Sc.; KHAIRIA A. EL-SAWI, D.N.Sc. and NAGAT E. IBRAHIM, D.N.Sc. \\ The Department of Medical Surgical Nursing, Faculty of Nursing, Cairo University
}

\begin{abstract}
Background: Hepatorenal syndrome is a unique form of functional renal failure due to diminished renal blood flow. It is a severe complication that affects patients with liver cirrhosis and ascites, the deterioration in kidney function is quantified by an elevation in creatinine level in the blood and decrease GFR. Assessing QOL of individuals with diseases has become common clinical practice. The aim of this study was to assess QOL among liver cirrhosis patients with HRS.
\end{abstract}

Patients and Methods: A convenient sample of 100 adult patients diagnosed with liver cirrhosis admitted in medical wards at one of Cairo University affiliated hospitals was recruited as study sample. A descriptive research design was utilized. Data was collected using 2 tools including tool 1 demographic and medical related data, tool 11, Quality of Life (QOL) for patients with chronic liver disease CLD.

Results: The study revealed that $(52 \%)$ of patients, their age above 50 years with mean of $(51.91 \pm 5.36)$, about $(78 \%)$ of patients were employmed have income more than 1000 L.E . As regard to medical data, about (55\%) have hepatitis $\mathrm{C}$, about $(77 \%)$ of patients were frequently readmitted complaining of hematemsis, there was decrease in GFR with increase in creatinine level, about (46\%-39\%-43\% and 32\%) of patients were feeling abdominal discomfort, feeling tired, muscles cramp, unable to hold or carry heavy objects respectively, while (51\% and $47 \%$ ) of patients were feeling unhappy and worried about the effect of disease on their family respectively. Finally the total mean score of QOL for patients with CLD of the studied sample equal $(96 \%)$ which indicating moderate QOL.

Conclusion: There was a moderate QOL among patients with HRS and there was relation between total scores of each domain and total QOL scores in CLD and between abdominal factors and other domains of QOL namely (fatigue, systemic symptom, activity and emotion) except worry. There was no relation between worry domain and other domains of QOL except emotion and there was a relation between worry domain and emotion domain.

Key Words: Quality of life (QOL) - Health related quality of life (HRQOl) - Hepatorenal syndrome (HRS) Chronic liver disease (CLD) - Creatinine (Cr) Glomerular filtration rate (GFR).

Correspondence to: Dr. Entesar S.M. Ahmad, The Department of Medical Surgical Nursing, Faculty of Nursing, Cairo University

\section{Introduction}

HEPATORENAL Syndrome (HRS) is one of the serious complications of liver cirrhosis. It is a failure of the kidneys secondary to chronic liver disease. Symptom include oliguria without detectable kidney damage, reduce Glomerular Filtration Rate (GFR) with essentially no urine output or less than $200 \mathrm{ml}$ per day and nearly an increase in serum sodium retention. It has two types, in type one there is a rapid progressive impairment of serum creatinine more than $2.5 \mathrm{mg} / \mathrm{dl}$, while in type two there is slower progressive reduction of GFR \& serum creatinine (1.5-2.5) [1]. The common manifestations on patients are easily fatiguability, dyspnea, tremors, gastro intestinal disturbances, insomnia, cognitive changes, edema of the lower limb, ascities, bleeding tendency, depression, and loss of self-esteem. These manifestations can tremendously affect patients ability to fulfill the activities of daily living having a major impact on patient quality of life [2]

Quality of Life (QOL) is a term used interchangeably with sickness impact profile. It is a multidimensional construct encompassing perceptions of both positive and negative aspects of physical, emotional, social, and cognitive function, as well as the negative aspects of somatic discomfort and other symptoms produced by a disease or its treatment. Quality of life is defined as the individual's perception of their position in life in the context of the cultural and value systems where they live and in relation to their goals, expectation, standards and concerns. It involves aspects of physical health, psychological state, level of dependency, social relationship, environmental factors and person beliefs [3].

The ultimate goal of health care is to restore or preserve functioning and well-being related to health that is Health Related Quality of Life (HRQOL). This is through quantifying the degree 
to which the medical condition or its treatment impact the individual life in a valid way. Health Related Quality of Life (HRQOL) is an important indicator along with traditional measures to capture the burden of disease or illness [3]

The aim of this study is to assess quality of life among patients with chronic liver disease with Hepatorenal Syndrome at one of Cairo University hospitals.

\section{Patients and Methods}

The study was conducted in medical wards at one of Cairo University Hospitals. The wards offer services to patient with different medical conditions including patients with liver cirrhosis. The number of these medical wards in the hospital are eight wards. The study was conducted at four out of the eight wards which were randomly selected. A sample of one hundred patients admitted to medical wards with a diagnosis of liver cirrhosis who are complicated with hepatorenal syndrome were selected for this study. Data was collected over a period of one year (July 2015 to July 2016).

Descriptive design was utilized using the appropriate statistical method. This design aims to gain more information about characteristics within particular field of study. Its purpose is to provide a picture of a situation as it naturally happens [4]

The study sample was selected according to the following inclusion criteria (1) Adults of both sexes with age above 30 years. (2) Having a confirmed diagnosis of chronic liver disease at least for the past six months (3) Patients complicated with hepatorenal syndrome, (4) Fully conscious patients. Patients with chronic disease as cardiac and renal disease were excluded.

Data were collected through structured personal interview utilizing the following tools:

1- Patient Personal Data (PPD): Including:

A- Demographic data form: This was developed and collected by the investigator. It included data such as name, age, sex, marital status, level of education, employment status, number of children, income, place of residency and its nature.

B- Clinical data form: This was developed by the investigator and included the past and present medical history, current medication and lab investigation.

2- Quality of life index for patients with chronic liver disease. (The Arabic Version) the tool was originally developed by Younossi, et al., 1999,
[5] it was translated and tested for reliability by El-Gilany and Alam 2015 [6]. The tool tested for reliability using test-retest method and the cronbach's alpha of the overall score was 0.86 and ranged from 0.80 to 0.91 in different domains.

The tool measures changes in quality of life over time within individuals with CLD. It consistes of 29 items covering the following domains: (1) Abdominal Symptoms (AS), 3 items. (2) Fatigue (FA), 5 items. (3) Systemic Symptoms, (SS) 5 items, (4) Activity, (AC) 3 items (5) Emotional Function, (EF) 8 items and (6) Worry, (WO) 5 items. Each statement is measured by 7 points Likert scale.

Scoring system: Patients quality of life was assessed according to the following scoring system putting into consideration that the higher the score the better quality of life will be. The scores ranges are (29-77) indicating low QOL, (78-173) indicating moderate QOL, and (174-203) indicating high QOl.

For ethical reasons an official permission was granted from the research ethical committee as well as the hospital administrators. Also each patient was informed about purpose of the study and its importance. The investigator emphasized to the patients to be studied that participation in the study was entirely voluntary. Confidentiality was assured through coding the data Informed consent was taken from each patient who accept to participate in the study.

Each patient who fit the study criteria was contacted by the researcher during their hospitalization to explain the purpose of the study. At that time demographic data was collected. The investigator fill out the quality of life tool for the selected patients before being discharged.

Statistical analysis of collected data was summarized and tabulated using SPSS program. Descriptive statistics was done using frequency, percentage distribution, mean and standard deviation.

\section{Results}

Statistical findings of the current study are presented in the following two parts:

Part I:Demographic and clinical data among the studied sample (Table 1).

Part II: Quality of life domains and its related sub factors Table (2A-C). 
Part III: Total quality of life among the studied sample Fig. (1).

Demographic and clinical data among the studied sample:

The study finding revealed that among the one hundred studied patients the mean age was (51.9 $1 \pm$ 5.36), as regard to residence about (99\%) of the patients were living in urban areas. Less than half of the sample, about (42\%) were having post secondary diploma. As regard to employment status the majority number of the studied sample $(78 \%)$ were employed, and (84\%) have monthly income of more than 1000 L.E. Regarding past history of illness all patients were diagnosed as having liver cirrhosis and $(55 \%)$ of them have hepatitis $\mathrm{C}$, about (77\%) of patients were frequently readmitted complaining of hematemsis.

Table (1) showed that $(63 \%)$ of patients have creatinine level ranging between $(1.5-2.5) \mathrm{mg} / \mathrm{L}$, and $(42 \%)$ have glumuler filtration rate between $(50-60) \mathrm{mm} / \mathrm{L}$.

Table (2A) showed that about (45\%-39\%) of studied sample feel abdominal discomfort and were feeling tired a good bit of the time respectively.

Table (2B) shows that about (43\%) of patients feel muscles cramp a good bit of the time, about $(43 \%)$ of patients have limitation to diet, $(37 \%)$ not able to eat what they want, while (32\%) of patients were unable to hold or carry heavy objects a good bit of the time.
Table (2C) showed that most of the studied sample about $(51 \%)$ of patients have worry, $(47 \%)$ of patients feeling unhappy, some of the time, about $(47 \%)$ of the studied sample reported worry about effect of disease on family a good bit of the time.

Fig. (1) illustrates that the total mean scores of quality of life for patients of the studied sample equal $(96 \%)$ indicating moderate quality of life.

Table (1): Frequency and percentage distribution of specific laboratory data among the studied patients $(n=100)$.

\begin{tabular}{lcc}
\hline Variables & $\mathrm{N}$ & $\%$ \\
\hline Creatinine: & & \\
$1.5-2.5 \mathrm{mg} / \mathrm{dl}$ & 63 & 63 \\
2.6-3.5mg/dl & 16 & 16 \\
Above 3.5mg/dl & 21 & 21 \\
GFR: & & \\
50-60mg/L & 42 & 42 \\
40-49mg/L & 29 & 29 \\
Less than 39mg/L & 29 & 29 \\
AST: & & \\
40-60mg/dl & 55 & 55 \\
61-80mg/dl & 18 & 18 \\
More than 80mg/dl & 27 & 27 \\
ALT: & & \\
$40-60 \mathrm{mg} / \mathrm{dl}$ & 53 & 53 \\
61-80mg/dl & 16 & 16 \\
More than 80mg/dl & 31 & 31 \\
\hline
\end{tabular}

Table (2A): Frequency and percentage distribution of abdominal factors and fatigue factors of quality of life $\mathrm{n}=100$.

\begin{tabular}{|c|c|c|c|c|c|c|c|c|c|c|c|c|c|c|c|}
\hline \multirow{2}{*}{$\begin{array}{l}\text { Que } \\
\text { No. }\end{array}$} & \multirow{2}{*}{ Domain } & \multicolumn{2}{|c|}{$\begin{array}{c}\text { All of } \\
\text { the time }\end{array}$} & \multicolumn{2}{|c|}{$\begin{array}{l}\text { Most of } \\
\text { the time }\end{array}$} & \multicolumn{2}{|c|}{$\begin{array}{l}\text { A good bit } \\
\text { of the time }\end{array}$} & \multicolumn{2}{|c|}{$\begin{array}{l}\text { Some of } \\
\text { the time }\end{array}$} & \multicolumn{2}{|c|}{$\begin{array}{l}\text { Alittle of } \\
\text { the time }\end{array}$} & \multicolumn{2}{|c|}{$\begin{array}{l}\text { Any of } \\
\text { the time }\end{array}$} & \multicolumn{2}{|c|}{$\begin{array}{l}\text { None of } \\
\text { the time }\end{array}$} \\
\hline & & $\mathrm{N}$ & $\%$ & $\mathrm{~N}$ & $\%$ & $\mathrm{~N}$ & $\%$ & $\mathrm{~N}$ & $\%$ & $\mathrm{~N}$ & $\%$ & $\mathrm{~N}$ & $\%$ & $\mathrm{~N}$ & $\%$ \\
\hline & I- Abdominal factors: & & & & & & & & & & & & & & \\
\hline 1 & Feeling of gas in stomach & 1 & 1.0 & 17 & 17.0 & 46 & 46.0 & 24 & 24.0 & 11 & 11.0 & 0 & 0.0 & 1 & 1.0 \\
\hline 5 & Feeling stomachache & 0 & 0.0 & 23 & 23.0 & 32 & 32.0 & 38 & 38.0 & 6 & 6.0 & 1 & 1 & 0 & 0.0 \\
\hline \multirow[t]{3}{*}{17} & Abdominal discomfort & 0 & 0.0 & 15 & 15.0 & 45 & 45.0 & 23 & 23.0 & 15 & 15.0 & 2 & 2 & 0 & 0.0 \\
\hline & Total & 1 & & 55 & & 123 & & 85 & & 32 & & 3 & & 1 & \\
\hline & II- Fatigue factors: & & & & & & & & & & & & & & \\
\hline 2 & Feeling tired or fatigued & 3 & 3.0 & 16 & 16.0 & 39 & 39.0 & 28 & 28.0 & 14 & 14.0 & 0 & 0 & 0 & 0.0 \\
\hline 4 & Feeling sleepy during the day & 1 & 1.0 & 8 & 8.0 & 32 & 32.0 & 39 & 39.0 & 19 & 19.0 & 1 & 1 & 0 & 0.0 \\
\hline 8 & Lack strength feeling of body & 0 & 0.0 & 17 & 17.0 & 33 & 33.0 & 36 & 36.0 & 14 & 14.0 & 0 & 0 & 0 & 0.0 \\
\hline 11 & Decrease level of energy & 1 & 1.0 & 15 & 15.0 & 27 & 27.0 & 37 & 37.0 & 20 & 20.0 & 0 & 0 & 0 & 0.0 \\
\hline \multirow[t]{2}{*}{13} & Drowsy & 1 & 1.0 & 13 & 13.0 & 27 & 27.0 & 31 & 31.0 & 28 & 28.0 & 0 & 0 & 0 & 0.0 \\
\hline & Total & 6 & & 69 & & 158 & & 171 & & 95 & & 1 & & 0 & \\
\hline
\end{tabular}


Table (2B): Frequency and percentage distribution of systemic symptom factors and activity factors of quality of life $\mathrm{n}=100$.

\begin{tabular}{|c|c|c|c|c|c|c|c|c|c|c|c|c|c|c|c|}
\hline \multirow[t]{2}{*}{$\begin{array}{l}\text { Que } \\
\text { No. }\end{array}$} & \multirow[t]{2}{*}{ Domain } & \multicolumn{2}{|c|}{$\begin{array}{l}\text { All } \\
\text { of the } \\
\text { time }\end{array}$} & \multicolumn{2}{|c|}{$\begin{array}{l}\text { Most } \\
\text { of the } \\
\text { time }\end{array}$} & \multicolumn{2}{|c|}{$\begin{array}{l}\text { A good } \\
\text { bit of } \\
\text { the time }\end{array}$} & \multicolumn{2}{|c|}{$\begin{array}{l}\text { Some } \\
\text { of the } \\
\text { time }\end{array}$} & \multicolumn{2}{|c|}{$\begin{array}{l}\text { Alittle } \\
\text { of the } \\
\text { time }\end{array}$} & \multicolumn{2}{|c|}{$\begin{array}{l}\text { Hardly } \\
\text { any of } \\
\text { the time }\end{array}$} & \multicolumn{2}{|c|}{$\begin{array}{l}\text { None } \\
\text { of the } \\
\text { time }\end{array}$} \\
\hline & & $\mathrm{N}$ & $\%$ & $\mathrm{~N}$ & $\%$ & $\mathrm{~N}$ & $\%$ & $\mathrm{~N}$ & $\%$ & $\mathrm{~N}$ & $\%$ & $\mathrm{~N}$ & $\%$ & & $\%$ \\
\hline & III- Systemic symptom factors: & & & & & & & & & & & & & & \\
\hline 3 & Feeling pain in body & 0 & 0.0 & 21 & 21.0 & 28 & 28.0 & 31 & 31.0 & 19 & 19.0 & 1 & 1 & 0 & 0.0 \\
\hline 6 & Daily Shortness of breath during activities & 1 & 1.0 & 6 & 6.0 & 18 & 18.0 & 43 & 43.0 & 32 & 32.0 & 0 & 0 & 0 & 0.0 \\
\hline 21 & Having muscles cramps & 0 & 0.0 & 5 & 5.0 & 43 & 43.0 & 30 & 30.0 & 16 & 16.0 & 5 & 5 & 1 & 1.0 \\
\hline 23 & Dry mouth & 0 & 0.0 & 0 & 0.0 & 10 & 10.0 & 19 & 19.0 & 69 & 69.0 & 2 & 2 & 0 & 0.0 \\
\hline \multirow[t]{3}{*}{27} & Skin itching & 1 & 1.0 & 0 & 0.0 & 2 & 2.0 & 5 & 5.0 & 73 & 73.0 & 15 & 15 & 3 & 3.0 \\
\hline & Total & 2 & & 32 & & 101 & & 128 & & 209 & & 23 & & 4 & \\
\hline & IV-Activity factors: & & & & & & & & & & & & & & \\
\hline 7 & Not able to eat what be wanted & 3 & 3.0 & 28 & 28.0 & 37 & 37.0 & 26 & 26.0 & 6 & 6.0 & 0 & 0 & 0 & \\
\hline 9 & Unable to hold or carry heavy objects & 4 & 4.0 & 27 & 27.0 & 32 & 32.0 & 29 & 29.0 & 8 & 8.0 & 0 & 0 & 0 & 0.0 \\
\hline \multirow[t]{2}{*}{14} & Limitation of diet & 2 & 2.0 & 11 & 11.0 & 43 & 43.0 & 31 & 31.0 & 13 & 13.0 & 0 & 0 & 0 & 0.0 \\
\hline & Total & 9 & & 66 & & 112 & & 86 & & 27 & & 0 & & 0 & \\
\hline
\end{tabular}

Table (2C): Frequency and percentage distribution of emotion and worry factors of quality of life n=100.

\begin{tabular}{|c|c|c|c|c|c|c|c|c|c|c|c|c|c|c|c|}
\hline \multirow[t]{2}{*}{$\begin{array}{l}\text { Que } \\
\text { No. }\end{array}$} & \multirow[t]{2}{*}{ Domain } & \multicolumn{2}{|c|}{$\begin{array}{l}\text { All } \\
\text { of the } \\
\text { time }\end{array}$} & \multicolumn{2}{|c|}{$\begin{array}{l}\text { Most } \\
\text { of the } \\
\text { time }\end{array}$} & \multicolumn{2}{|c|}{$\begin{array}{l}\text { A good } \\
\text { bit of } \\
\text { the time }\end{array}$} & \multicolumn{2}{|c|}{$\begin{array}{l}\text { Some } \\
\text { of the } \\
\text { time }\end{array}$} & \multicolumn{2}{|c|}{$\begin{array}{l}\text { Alittle } \\
\text { of the } \\
\text { time }\end{array}$} & \multicolumn{2}{|c|}{$\begin{array}{l}\text { Hardly } \\
\text { any of } \\
\text { the time }\end{array}$} & \multicolumn{2}{|c|}{$\begin{array}{l}\text { None } \\
\text { of the } \\
\text { time }\end{array}$} \\
\hline & & $\mathrm{N}$ & $\%$ & $\mathrm{~N}$ & $\%$ & $\mathrm{~N}$ & $\%$ & $\mathrm{~N}$ & $\%$ & $\mathrm{~N}$ & $\%$ & $\mathrm{~N}$ & $\%$ & $\mathrm{~N}$ & $\%$ \\
\hline & V- Emotional factors: & & & & & & & & & & & & & & \\
\hline 10 & Feeling worry & 0 & 0.0 & 2 & 2.0 & 26 & 26.0 & 51 & 51.0 & 20 & 20.0 & 1 & 1 & 0 & 0.0 \\
\hline 12 & Feeling unhappy & 0 & 0.0 & 1 & 1.0 & 12 & 12.0 & 47 & 47.0 & 39 & 39.0 & 1 & 1 & 0 & 0.0 \\
\hline 15 & Feeling tense & 1 & 1.0 & 3 & 3.0 & 14 & 14.0 & 47 & 47.0 & 35 & 35.0 & 0 & 0 & 0 & 0.0 \\
\hline 16 & Having difficulty sleeping at night & 0 & 0.0 & 8 & 8.0 & 25 & 25.0 & 40 & 40.0 & 24 & 24.0 & 1 & 1 & 2 & 2.0 \\
\hline 19 & Feeling mood swings & 0 & 0.0 & 1 & 1.0 & 5 & 5.0 & 50 & 50.0 & 43 & 43.0 & 1 & 1 & 0 & 0.0 \\
\hline 20 & Falling asleep at night & 1 & 1.0 & 8 & 8.0 & 22 & 22.0 & 53 & 53.0 & 11 & 11.0 & 1 & 1 & 4 & 4.0 \\
\hline 24 & Feeling of depression & 0 & 0.0 & 0 & 0.0 & 2 & 2.0 & 20 & 20.0 & 74 & 74.0 & 2 & 2 & 2 & 2.0 \\
\hline \multirow[t]{3}{*}{26} & Problem of concentration & 0 & 0.0 & 1 & 1.0 & 14 & 14.0 & 64 & 64.0 & 21 & 21.0 & 0 & 0 & 0 & 0.0 \\
\hline & Total & 2 & & 24 & & 120 & & 372 & & 267 & & 7 & 7 & 8 & \\
\hline & VI- Worry factors: & & & & & & & & & & & & & & \\
\hline 18 & Worry about effect of disease on family & 0 & 0.0 & 4 & 4.0 & 47 & 47.0 & 22 & 22.0 & 24 & 24.0 & 3 & 3 & 0 & 0.0 \\
\hline 22 & Worried about progress of disease & 0 & 0.0 & 5 & 5.0 & 26 & 26.0 & 42 & 42.0 & 25 & 25.0 & 0 & 0 & 2 & 2.0 \\
\hline 25 & Worried about deterioration of disease & 0 & 0.0 & 4 & 4.0 & 28 & 28.0 & 32 & 32.0 & 34 & 34.0 & 2 & 2 & 0 & 0.0 \\
\hline 28 & Worried that condition may not improve & 0 & 0.0 & 3 & 3.0 & 12 & 12.0 & 17 & 17.0 & 33 & 33.0 & 35 & 35.0 & 0 & 0.0 \\
\hline \multirow[t]{2}{*}{29} & Availability of liver transplant & 0 & 0.0 & 0 & 0.0 & 9 & 9.0 & 15 & 15.0 & 70 & 70.0 & 5 & 5.0 & 1 & 1.0 \\
\hline & Total & 0 & & 16 & & 122 & & 128 & & 186 & & 45 & & 3 & \\
\hline
\end{tabular}

Frequency distribution of the sample according to QOL

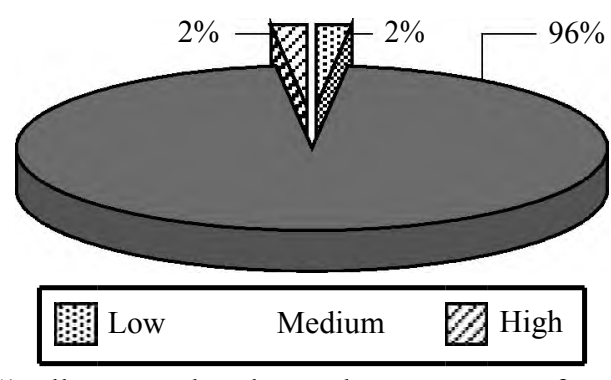

Fig. (1): Illustrates that the total mean scores of quality of life for patients of the studied sample equal (96\%) indicating moderate quality of life.

\section{Discussion}

Part I: Demographic and medical related data for patient with liver disease:

The demographic data of this study subjects revealed that more than half of the subjects aged more than fifty years with a mean of $(51.91 \pm 5.36)$. This study was supported by a study of Kim et al., [7] who assessed aging and liver disease and found that there is gradual alteration of hepatic structure and function as well as various changes in liver cells including hepatic sinusoidal endothelial cells by age. Aging can also increase the risks for various 
liver diseases and acts as an adverse prognostic factor, causing an increase in the mortality rate. Age is a major risk factor for most chronic diseases because the volume and blood flow of the liver gradually decrease up to thirty five percentage in people aged sixty five years as compared with those aged less than forty years. About ninety nine of patients were living in urban areas. This study finding disagree with study of Malhotra et al., [8] that assessed incidence of chronic liver disease patients, delineating that eighty one percentages of patients were living in rural area.

This study showed that the majority of studied patients were educated and nearly half of them hold post secondary diploma. This study disagree with Feldeli et al., [9] who investigated educational level and chronic liver disease and noted that ninty five percentage of patients have primary education, their rationale for that is, because the risk for alcohol-related and non-viral/non-alcohol-related disease significantly increased with lower education in both genders. Regarding to the study findings about monthly income more than three quarters of the studied sample have monthly income more than one thousand L.E/month. This study was supported by another study to assess quality of life in chronic liver disease, they noted that about (42.9\%) of their sample employed and had a family income more than a thousand L.E (43.6\%) [10]

Finding also revealed that among the studied patients, more than half of them have Hepatitis $\mathrm{C}$ in active stage. A supporting study by James et al., [8] found that Hepatitis $\mathrm{C}$ is a major liver disease world wide. In relation to the number of previous hospitalization and reasons for hospitalization more than three quarters of sample were admitted more than ten times. More than three quarters suffer from hematemsis and nearly one quarter came for follow-up endoscopy. This agreed with a study mentioned that Cirrhosis is the most common cause of portal hypertension which lead to hematemsis [11].

Laboratory investigation results of the study subjects delineated a decrease in GFR with a value of (50-60) $\mathrm{mg} / \mathrm{dl}$ which appears in about half of the sample, GFR value of less than $39 \mathrm{mg} / \mathrm{dl}$ was evident among nearly one third of the sample. For creatinine increased value, laboratory investigation results denoted that among more than half of the sample have creatinine value of (1.5-2.5) $\mathrm{mg} / \mathrm{dl}$ and (above 3.5) $\mathrm{mg} / \mathrm{dl}$ among one fifth of the sample. The decrease in GFR and increase in creatinine value constitute poor prognosis for patients with hepatorenal syndrome. Studies sup- porting this finding stated that serum creatinine values of more than one point five $\mathrm{mg} / \mathrm{dL}$ is a relatively benign and potentially reversible condition, where as the progression of renal deterioration to a significant decrease in GFR carried a poor prognosis $[12,13]$.

\section{Part II: Findings related to quality of life:}

The study finding denoted a medium level QOL among ninety six percentage of patients. A study that found a different results indicated an impaired HRQOL among patients with liver cirrhosis as compared to those without liver diseases, the author added that many studies using different tools of HRQOL among similar population denoted an impairment of HRQOL whether due to mental impairment or limitation affecting patients ability to perform activity of daily living [14]

In relatin to the domain of abdominal factors about half of the sample showed feeling of gas in stomach and abdominal discomfort. Regarding to patients with Hepatitis C, QOL scores were better than Non Alcoholic Fatty Liver Disease (NAFLD) in two domains including emotional and systemic symptoms but worse than HBV in two domains (abdominal symptoms and activity) [15]

For the fatigue domains more than half of subjects reported feeling tired and lack strength feeling of body and there were high significant relation between fatigue domain and all other domains related to quality of life except worry domain. This finding was supported by a study which stated that Fatigue is a prominent symptom in patients with chronic liver disease particularly those with chronic hepatitis $\mathrm{C}$. They found that fatigue affects patients with chronic hepatitis $\mathrm{C}$ at prevalence rates between $50 \%$ and $75 \%$ [16]. Moreover study of Preto et al., [17], who assessed quality of life and chronic diseases mention that chronic diseases cause changes in the routine and activity planning in which the individual stops carrying out his or her daily activities. The physical, emotional and financial overload lead the individual to deal with insecurity and social dilemmas, in addition to heavy expenses, which generate other chronic conditions that can affect the whole family.

Regarding to systemic symptoms nearly half of the studied sample reported feeling of pain, and having muscles cramp. A study revealed that $(67 \%)$ of patients with liver cirrhosis feeling muscle cramps and patients with cramps had significantly lower serum albumin and QOL for patients with chronic liver disease scores [18] 
For activity factors. This study found that more than half of the studied sample felt unable to hold heavy objects and had limitation of diet. There is high significant relation between activity domain and other domain except worry. This was supported by study of Ney et al., [19], as their study subjects had significant barriers regarding adoption of nutritional and physical activity interventions in patients with cirrhosis, especially as disease severity worsens but even in compensated patients.

As regard to worry domain the current study showed that nearly half of the sample worried about effect of disease on family, this was in disagreement with study of Alghazaly, [20], they mentioned that more than eighty three percentage of patients had never been or rarely worried about the impact of their liver disease on their family.

As regarded to emotional factors, this study finding revealed that more than half of the sample reported feeling unhappy. This is in agreement with the study of Megari, [21] who assess quality of life in chronic illness and revealed that there were factors associated with low health related quality of life in chronic disease such as diabetes, HIV and Hepatitis C. Poor HRQoL is associated with a number of factors such as coexisting chronic diseases, adverse health risk behaviors like smoking, obesity, and physical inactivity are associated with decreased HRQoL in patients. Depressive symptoms in Hepatitis C patients were found to be connected to poor HRQoL.

\section{Recommendation:}

To improve quality of life among liver cirrhosis patients with hepatorenal syndrome nurses should do the following:

- Instruct patients for importance of periodic check up specific laboratory investigation for those above 50 years suffering from chronic liver disease, to help in early detection of poor prognosis and help in early treatment as we can.

- Utilize non pharmacological measures to relieve certain complains as abdominal discomfort and pain.

- Improving knowledge level by raising awareness regarding the recent available treatment of Hepatitis $\mathrm{C}$.

- Health teaching about Hepatitis $\mathrm{C}$ its transmission, how to protect others from infection.

- Repeat the study on a larger sample in different places in the Arab Republic of Egypt in order to disseminate the results.

\section{References}

1- WILLIAM L. and HOPPER P.: Text book of Understanding Medical Surgical nursing 4 th Philadelphia, Pp. 786-7, 2012.

2- SMELTZER S., BARE B.,HINKLE J. and CHEEVER K.: Brunner \& Suddarth,s., text book of medical surgical nursing 12th ed. Lippincott, Pp. 1124-1125-1146-1147, 2011 .

3- PALMA D. and LARSEN R.: Text book in chronic illness impact and interventions 5 th edition, pp. 182-3, 2007.

4- BURNS N. and GROVE S.: Text book of understanding nursing research building an evidence based practice 5 th ed. Elsevier, Pp. 256, 2011.

5- YOUNOSSI Z., et al.: Development of disease specific Questionnaire to measure health related Quality Of Life in patients with Chronic Liver Disease Available @ : http://gut.bmj.com/content/45/2/295.full.html, 1999.

6- EL-GILANY A. and ALAM R.: Study of Quality of life of Elderly with Chronic liver diseases. Journal of nursing and Health science, Volume (4) Issue (4) Pp. 35-41, 2015.

7- KIM H., KISSELEVA T. and BRENNER D.: Review on aging and liver disease, 31 (3): 184-91, 2015.

8- MALHOTRA P., et al.: Haryana in grip of Hepatitis C Journal of medicine and Medical Science, Volume (3) pp. 8, 2016.

9- FEDELI U., et al.: Text book on Digestive and Liver disease, Educational level and Chronic Liver Disease by etiology: A proportional mortality study, Volume 47, Issue 12, PP. 1082-5, 2015.

10- SOUZA N., et al.: Review on assessment of health related quality of life and related factors in patients with chronic liver disease available at Brazilian Journal of Infectious Diseases Volume 19 No. 6 salvador, 2015.

11- SAUERBRUCH T. \& TREBICKA J.: Review of Future therapy of portal hypertension in liver cirrhosis. Journal F1000 prime reports, V. 6, 2014.

12- BARALDI O., et al.: Hepatorenal syndrome: Up Date on Diagnosis and Treatment World Journal of Nephrology, 4 (5): 511-20, 2015.

13- FAGUNDES C., et al.: A modified acute kidney injury classification for diagnosis and risk stratification of impairment of kidney function in cirrhosis. J. Hepatol., 59 (3): 474-81. Doi 10.1016, 2013.

14- YOUNOSSI Z. and HENRY L.: Overall health-related quality of life in patients with end-stage liver disease. Chronic liver disease. A Multimedia Review Journal, Volum 6 (1) pp. 9-14, 2015.

15- JAMES R., et al.: A study of Health related Quality of life in people with advanced Chronic liver disease, Journal of Hepetology, Volum 61, pp. 1158-65, 2014.

16- JORGENSEN R.: A study on Fatigue and disease trajectories in chronic liver disease patients: The role of Gender and coexistent symptoms available at https://conservancy. umn.edu/handle/11299/96587, 2010.

17- PRETO O., et al.: Study of Quality of life and chronic disease in patients receiving primary Health care available at eISSN, 2357-1330 Pp. 225, 2016. 
18- CHATRATH H., et al.: Review in prevalence and morbidity associated with muscles cramps in patients with cirrhosis. American Journal of Medicine, 125 (10): 101925, 2012.

19- NEY M., et al.: Patient-Perceived Barriers to Lifestyle Interventions in Cirrhosis. Saudi Journal of Gastrenterology, 239: 97-104, 2017.
20- ALGHAZALY G., ABD EL RAOUF Y.M. and Zaglol K.H.: Impact of chronic liver disease on health related quality of life and its association with anaemia in AlGharbiyah Governorate, Egypt, ISSN: 2315-5159 Issue Volum 5 (2), pp. 053-066, 2016.

21- MEGARI K.: Study of Quality of life in Chronic Disease patients, Journal of Health Psychology Research, v 1 (3) e 27, 2013.

\section{نوعية الحياة لمرضى الكبد المصاحب بالمتلازمة الكبدية الكلوية}

يعتبر مرض التليف الكبدى آحد الآمراض التى تهدد حياة الإنسان حيث آنه يحدث خلل في وظائف الكبد وترجع الإصابة به لعدة آسباب

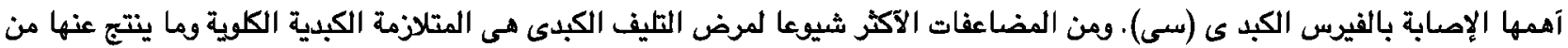

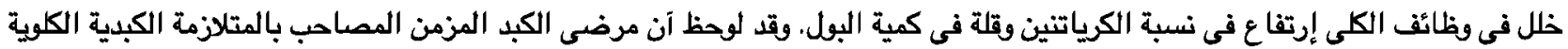

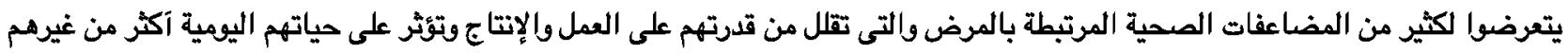

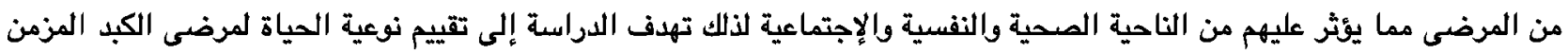

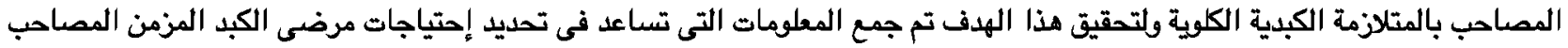

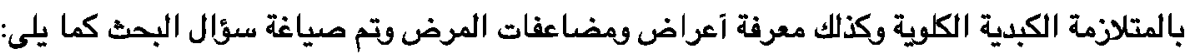
ما هى نوعية الحياة لمرضى الكبد المزمن المصاحب بالمتلازمة الكبدية الكلوية؟

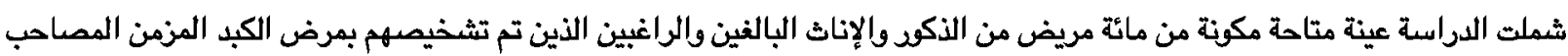

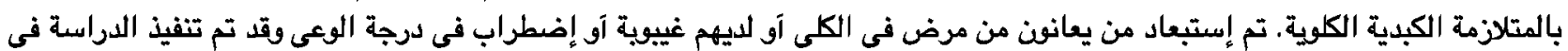



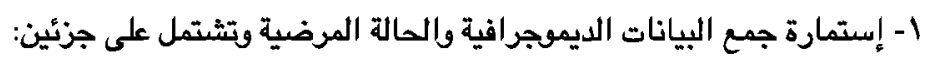

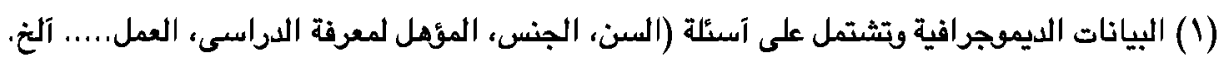

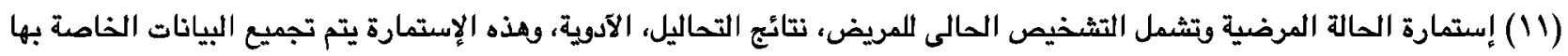

$$
\text { من الملف الطبى المريض. }
$$

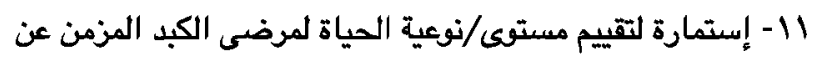

Younossi, Guyatt, kiwi, Boparai \& king (1999)

El-Gilany A., Alam R. (2015) والمترجمة للعربية بواسطة الباحث عن

وقد آجريت الدراسة الحالية بمقابلة المرض المشاركين مرة واحدة خلال تواجدمم بقسم الباطنة وتمت خلال المقابلة ملء الإستمارات الللازمة الباتية

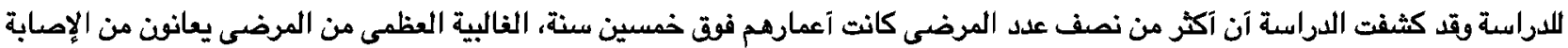

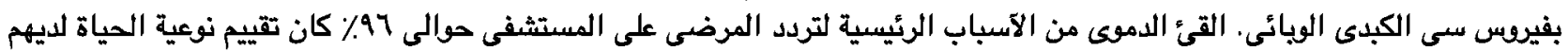



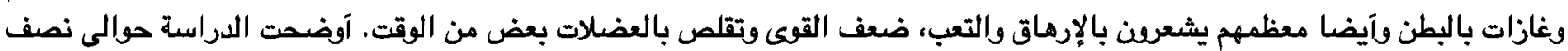

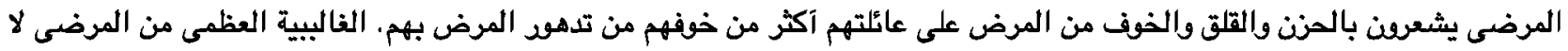

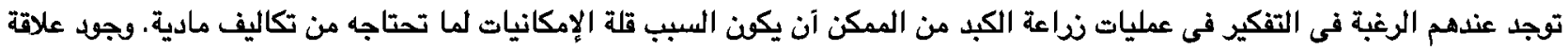

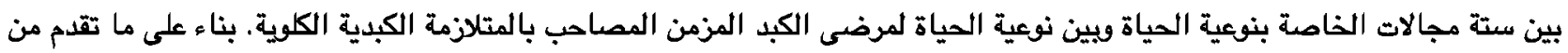

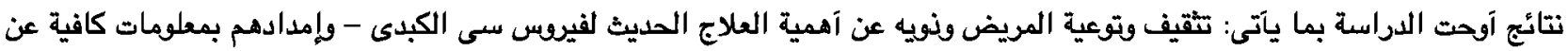

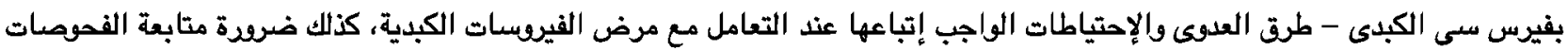

